\title{
Employer attractiveness: Measurement scale development and validation
}

\author{
Nguyen Minh $\mathrm{Ha}^{1}$, Nguyen Vinh Luan ${ }^{1,2^{*}}$, Nguyen Minh Trung ${ }^{3}$ \\ ${ }^{1}$ Ho Chi Minh City Open University, Vietnam \\ ${ }^{2}$ Imexpharm Pharmaceutical Joint Stock Company, Dong Thap Province, Vietnam \\ ${ }^{3}$ The Member of Tan Phu District Party Inspection Committee, Ho Chi Minh City, Vietnam \\ *Corresponding author: luannguyenvinh@gmail.com
}

\begin{tabular}{|c|c|}
\hline ARTICLE INFO & ABSTRACT \\
\hline $\begin{array}{l}\text { DOI:10.46223/HCMCOUJS. } \\
\text { econ.en.11.1.1367.2021 }\end{array}$ & $\begin{array}{l}\text { Human resource quality is one important factor that affects the } \\
\text { success of each organization. The need to build a human resource } \\
\text { foundation with knowledge, skills and good attitude is one urgent } \\
\text { task for all business leaders. The first task is to attract and recruit } \\
\text { excellent individuals to work for the business; therefore, how to } \\
\text { attract candidates is always academic researchers' as well as }\end{array}$ \\
\hline Received: December $24^{\text {th }}, 2020$ & business managers' top priority. Employer attractiveness factor \\
\hline Revised: January $25^{\text {th }}, 2021$ & (Berthon, Ewing, \& Hah, 2005) has been applied in some recent \\
\hline Accepted: January $26^{\text {th }}, 2021$ & $\begin{array}{l}\text { diverse and different for individual organizations, cultures and } \\
\text { countries, the scale of employer attractiveness concept still implies } \\
\text { many points that are not appropriate for Vietnamese contexts. This } \\
\text { research, based on the social exchange theory and the employer } \\
\text { branding theory, develops in great details and confirms the employer }\end{array}$ \\
\hline $\begin{array}{l}\text { Keywords: } \\
\text { employer attractiveness, } \\
\text { recruitment, employees, } \\
\text { safety value, social value, } \\
\text { development value, } \\
\text { application value, economic } \\
\text { value }\end{array}$ & $\begin{array}{l}\text { (interviewing } 4 \text { experts and } 2 \text { staff in-depth groups as well as } \\
\text { surveying quantitatively } 937 \text { employees working for Vietnamese } \\
\text { enterprises) has been applied. The research results determine the } \\
\text { employer attractiveness dimension factor comprising social value, } \\
\text { development value, application value, safety value and economic } \\
\text { value. This research has discovered a new factor of employer } \\
\text { attractiveness scale: safety value. }\end{array}$ \\
\hline
\end{tabular}

\section{Introduction}

Activities to attract and retain employees, one crucial strategy, identifies human resource quality in each organization and affects business success or failure. Therefore, many researchers and practitioners have analyzed and explored the most fundamental solutions to attract the best personnel working for the organization. The starting point is Berthon et al. (2005), in which, employer attractiveness is the benefit of an organization perceived by potential candidates as a particular workplace, presents the scale related to potential candidates' views on the company's attraction ability: interest, social, economic, development and application values. Following this first concept, Elving, Westhoff, Meeusen, and Schoonderbeek (2013) develops the new research direction in which employer brand is valued as the position of this organization in the market; especially, loyalty does help the organization to actively build an employer brand and contribute 
to organizational development. The diversity of different concepts on employer attractiveness factor refers to vocational behavior (Soutar \& Clarke, 1983), management (Gatewood, Gowan, \& Lautenschlager, 1993), psychology (Collins \& Steven, 2002; Jurgensen, 1978), communication (Bergstrom, Blumenthal, \& Crothers, 2002) and marketing (Ambler \& Barrow, 1996). Employer attractiveness, according to Jiang and lles (2011), refers to current and potential employees' awareness levels. This concept implies that marketing process effectiveness in one organization is better than that of its competitors with long-term and sustainable success. If analyzed in terms of recruitment activity, employer attractiveness is defined as the functional group comprised of the candidate's personality and the organization's features (Schreurs, Druart, Proost, \& De Witte, 2009). As a result, employer attractiveness can be classified into internal and external classification. In particular, internal employer attractiveness reflects the degree to which current employees feel attracted by the company's image. In contrast, the external employer attractiveness shows how attractive the company is to outside candidates (Pingle \& Sharma, 2013). In summary, Berthon et al.' scale (2005) has been applied because of popularity and suitability. In this study, the author is using Berthon et al.'s (2005) employer attractiveness scale as the foundation to develop and determine the scale.

\section{Literature review}

Internal branding emphasizes the role of the employee in one organization. The service and corporate branding theory indicate that employees influence both customers and stakeholders through their role in terms of what values they have performed and how emotional they are (de Chernatony, 2002). Employees have become the center of the branding process and their behavior will greatly contribute to the corporate brand image promotion. In other words, the employee's values and behavior may be similar to those expected by the organizational brand (Harris \& de Chernatony, 2001). Once the employee is aligned with brand value, the company can achieve a sustainable competitive advantage (Pringle \& Thompson, 2001). Consequently, internal branding is to gain a competitive advantage through employees' achievements (e.g., coring goals that are difficult to replicate from rival companies) (Jacobs, 2003). According to Aurand, Gorchels, and Bishop (2005) and Burmann and Zeplin (2005), internal branding is assumed to enable employees to perceive brand promise through services because of its impacts as a shared understanding in the organization. In addition, internal branding includes three roles as follows: effectively communicating corporate brand to employees, convincing them of relevant and valuable things, successfully linking all jobs in the organization (Bergstrom et al., 2002). In summary, internal branding is seen as a tool to influence employee attitudes and shape their behavior associated with the brand by giving employees knowledge related to the insight value of the brand name and the actual brand association (de Chernatony \& Segal-Horn, 2001; Drake, Gulman, \& Roberts, 2005; Thomson, Chernatony, Arganbright, \& Khan, 1999).

Employer branding theory was developed by Ambler and Barrow (1996) who combines marketing area and human resource major. The term 'employer branding' is composed of economic and psychological benefits. One cornerstone of employer branding theory is external marketing and internal marketing: external marketing builds the company as the first choice to attract the best candidates to join the company whereas internal marketing constructs one distinctive and unique working environment. Candidates can perceive the values of the working environment and organizational culture through the external manifestations of the company; e.g., development goals. On the other hand, that the employer branding activities help one company achieve the distinctive and unique organizational culture assists this company's business strategy implementation. In other words, creating a unique working environment for each company avoids being duplicated by competitors. In short, internal marketing not only contributes to employee 
retention but also uses brand strength to improve the overall quality of human resources (Ambler \& Barrow, 1996).

Besides the external marketing and internal marketing theoretical background, psychological contract theory is also an important basis for the employer branding theory. The psychological contract theory focuses on the relationship between the employee and the organization: The employees will have loyalty promise to the organization in return for job security (Hendry \& Jenkins, 1997). However, due to the impact of new trends (downsizing, outsourcing and flexibility), some companies have adjusted the psychological contract orientation: the company will proactively provide employees with the latest market skills through training and coaching programs; on the contrary, the employees will commit to doing his best at work (Baruch, 2004). In addition, companies, to address the employee's negative emotions, can use employer branding to increase attractiveness (training programs, career development opportunities, personal development, etc.). Consequently, the employer branding theory is judged as an effective strategy for companies to move from ineffective solutions to innovative solutions in relationships with employees (Hendry \& Jenkins, 1997; Newell \& Dopson, 1996).

From another perspective, employer branding theory influences brand equity concept formulation. In marketing, 'brand equity' term is defined as a set of brand assets and liabilities linked to a brand that add to or subtract from the value provided by a product or service to a firm and /or to that firm's customers' (Aaker \& Equity, 1991). Customers will depend on brand equity through brand knowledge impacts on customers' feedback (Keller, 1993). Brand equity can attract potential candidates as well as current employees to work long-term and dedicate themselves to the company. In other words, the fact that employees (current as well as potential) may face dissatisfactory issues in recruitment processes although companies make great efforts in the talent retaining process indicates the differences in brand equity of each company.

\section{Dimensions of employer attractiveness scale}

\subsection{Social value (SOC)}

This factor reflects the extent to which an individual is attracted to the employer by providing a fun and happy working environment, good working relationship and team atmosphere (Berthon et al., 2005). Social value (SOC) means an individual attracted to businesses due to the provision of a fun and happy working environment, good working relationship and a team atmosphere (Berthon et al., 2005). According to social exchange theory (Emerson, 1976), the trade-offs between employer and employee can be classified into tangible and intangible rewards (Edwards, 2010): Intangible reward, or the spiritual reward, refers to the social values provided to the employees (a fair, fun and supportive work environment) while the employees may provide the employer with the social value of engagement. Social value plays a very important role in maintaining the relationship between employee and employer in an organization. If an employee feels fit with organizational culture, they will tend to stay in the organization for a longer period (De Vos \& Meganck, 2009; Sheridan, 1992; Taormina, 2009; Zheng \& Lamond, 2010). Social value has a strong effect on employee identification in improving employee engagement (Schlager, Bodderas, Maas, \& Cachelin, 2011).

\subsection{Development value (DEV)}

Development value (DEV) shows an individual attracted to businesses by providing recognition, confidence, engagement with professional experience and a foundation for future growth (Berthon et al., 2005). Similar to social value, according to social exchange theory (Emerson, 1976), the value exchanged between employer and employee consists of material benefits and social 
benefits (Shore, Coyle-Shapiro, Chen, \& Tetrick, 2009). Accordingly, if the employer provides the employee with values (growth opportunities including work experience as the foundation for future growth or confidence in employee, etc.), the employees will devote their best ability to the employer (Berthon et al., 2005). Therefore, development value can imply a positive impact on employee engagement in the organization. According to Schlager et al. (2011), a strong mentoring culture, training opportunities and an empowering environment for employees are important criteria in evaluating an organization's growth value. At the same time, whatever form of development value an employee receives from the organization, this form will affect their commitment to the organization (Tansky \& Cohen, 2001). In addition, the development value also improves organizational identification (Lee, 1971). With this point of view, according to Parsley (2005), training activities, as well as career development opportunities in the organization, always have a positive impact on employee engagement. Specifically, 35\% of employees from this survey feel happy in the working environment of the organization with their career development opportunities.

\subsection{Application value (APP)}

Application value (APP) represents an individual who is attracted to businesses providing the opportunity to apply what they have been taught to coworkers in the humanistic and customeroriented working environment (Berthon et al., 2005). According to social identity theory, individuals tend to join a social group matching their interests within the company that is considered to be their identity. The employees feel a sense of belonging to this organization and comfortable presenting them. Therefore, they are willing to share their knowledge and experience to their colleagues. In addition, a customer-oriented working environment will have a positive impact on organizational commitment and organizational citizenship behavior (Donavan, Brown, \& Mowen, 2004). Furthermore, this value can affect employee turnover (Paré \& Tremblay, 2007) and employee retention (Paré, Tremblay, \& Lalonde, 2001). Furthermore, a humanistic and developmental orientation will create a long-term and sustainable relationship between employees and employer as well as the degree of engagement of employees with the organization (King \& Grace, 2008). On the other hand, the accumulation of practical experiences and learning opportunities will help maintain a skill-rich working environment in the organization (Kyndt, Dochy, \& Nijs, 2009).

\subsection{Safety value (SAF)}

Safety value (SAF) reflects the degree to which an individual is attracted to businesses for safety and security at work (Berthon et al., 2005). According to Hendler (2012), the role of employee awareness in the ethical leadership style increases employee engagement in one organization. Safety value is proved its leading role in leadership style and positive effects on employee engagement. In addition, Zohar, Huang, Lee, and Robertson (2015) discover that employee engagement is an intermediate variable between safety climate and safety behavior. In another study, Lyu (2016) found the intermediary role of psychological safety in the relationship between organizational justice and employee engagement. Thus, quite a few researchers have confirmed the impact of safety value on employee engagement. The researchers believe psychological safety helps improve job engagement because, in difficult situations (employees feeling hurt due to negative effects on the job), safety value is likely the key solution in solving problems and employees engaging more in their work (Kahn, 1990; Schneider, Macey, Barbera, \& Young, 2010).

\subsection{Economic value (ECO)}

Economic value (ECO) reflects the degree to which an individual is attracted by firms by providing average wages and competitive benefits and bonus packages (Berthon et al., 2005). 
According to the social exchange theory (Emerson, 1976), the fact that an individual's actions will depend on others' rewarding actions (Blau, 1964) suggests the value exchange between the two sides as long as each party believes in this fair and reasonable exchange. Economic value, an important factor in maintaining the relationship between employer and employee, has two important elements: exchange content and exchange process (Shore \& Coyle-Shapiro, 2003), especially, economic benefits. Employees contribute their abilities to the organization in order to receive economic rewards from the employer. Economic benefits depend on employees' effectiveness and capacity levels in contributing to the organization. In return, employees will contribute more to the organization if they receive the increased economic benefits from the organization. Economic value is understood to include competitive recognition and remuneration for employees. This value has a positive impact on the employee's attitude towards their intention to stay in the organization for a long time (Chew \& Chan, 2008). Therefore, when the organization provides the employees with high salaries and benefits, these activities will attract more potential employees and retain employees more effectively (Ash \& Bendapudi, 1996).

\section{Research methodology}

\subsection{Research methodology and sampling}

The mixed research method (qualitative research methods and quantitative research methods) is used to achieve the proposed research objectives. Qualitative research applies the expert interview method and group discussion. Participants in the discussion include 4 experts and 2 staff groups. The experts interviewed are four experts with Ph.D. qualifications: an expert in researching, an expert in marketing \& Journal editor, an expert with application experience in human resources (consultant) and a lecturer in human resources. Two discussion groups comprising employees with for 5 year working experience or more to clarify and modify words in the questionnaire. The group discussion is conducted under the author's chair with a discussion on the guide outline. The results of qualitative research summarize research concepts and employer attractiveness with 5 factors: social value (SOC), development value (DEV), application value (APP), safety value (SAFE) and economic value (ECO). In addition, through group discussion, the study scales are also adjusted to suit the surveyed subjects' thoughts.

In the next step, respondents surveyed by questionnaires focus on the employees currently working in enterprises located in Vietnam. As for the sample number, according to Hair, Sarstedt, Ringle, and Gudergan (2017), it is impossible to analyze a sample with fewer than 50 observations and preferably 100 or more observations. As a rule, the minimum number of observed samples must be equal to 5 times the number of observed variables. The acceptable sample level for sample size is 10:1 ratio. Some researchers propose, at least, 20 cases for each variable. According to Tabachnick, Fidell, and Ullman (2007), the sample sizes: 50 are very poor, 100 are bad, 200 are pretty good, 300 are good, 500 are great and 1000 are excellent. This means that researchers are always trying to achieve the highest number of cases per variable to help minimize the overfitting (deriving factors are sample-specific with low generalizability). To achieve this goal, researchers need to save on building variables guided by concepts and practices. In selecting a smaller sample size or a lower case-to-variable ratio, the researchers need a suitable explanation. Therefore, the number of 937 samples in this study is appropriate and meets the standard requirement and research resource optimization.

\subsection{Measurement}

All research concepts are based on previous studies, qualitative research results, adjusted through preliminary research and presented in statement form. Likert scale, with 5 levels from (1) Totally disagree to (5) Totally agree, is used as follows: 


\section{Table 1}

Employer attractiveness measurement scale

\begin{tabular}{|c|c|c|}
\hline No. & Dimensions & Resources \\
\hline I & Social value (SOC): 6 items & \\
\hline 1 & Colleagues in the company always get along with each other & Qualitative research \\
\hline 2 & Having a good relationship with your colleagues & Berthon et al. (2005) \\
\hline 3 & Supportive and encouraging colleagues & Berthon et al. (2005) \\
\hline 4 & Having a good relationship with your superiors & Berthon et al. (2005) \\
\hline 5 & Happy work environment & Berthon et al. (2005) \\
\hline 6 & A fun working environment & Berthon et al. (2005) \\
\hline II & Development value (DEV): 6 items & \\
\hline 1 & $\begin{array}{l}\text { You feel the desire to stick with the organization because of the } \\
\text { opportunities that come from experience in a professional workplace }\end{array}$ & Qualitative research \\
\hline 2 & $\begin{array}{l}\text { Feeling good about yourself as a result of working for a particular } \\
\text { organization }\end{array}$ & Berthon et al. (2005) \\
\hline 3 & $\begin{array}{l}\text { Feeling more self-confident as a result of working for a particular } \\
\text { organization }\end{array}$ & Berthon et al. (2005) \\
\hline 4 & A springboard for future employment & Berthon et al. (2005) \\
\hline 5 & Gaining career-enhancing experience & Berthon et al. (2005) \\
\hline 6 & My organization always implements decentralized employee & Qualitative research \\
\hline III & Application value (APP): 4 items & \\
\hline 1 & Opportunity to teach others what you have learned & Berthon et al. (2005) \\
\hline 2 & Opportunity to apply what was learned at a tertiary institution & Berthon et al. (2005) \\
\hline 3 & $\begin{array}{l}\text { You have the opportunity to share your real experiences with } \\
\text { everyone in the organization }\end{array}$ & Qualitative research \\
\hline 4 & Acceptance and belonging & Berthon et al. (2005) \\
\hline IV & Safety value (SAF): 3 items & \\
\hline 1 & $\begin{array}{l}\text { The organization I work with always ensures occupational safety } \\
\text { during work activities }\end{array}$ & Qualitative research \\
\hline 2 & Job security within the organization & Berthon et al. (2005) \\
\hline 3 & $\begin{array}{l}\text { The organization I work with is always safe in the work environment } \\
\text { (without pressure, sexual harassment, etc.) }\end{array}$ & Qualitative research \\
\hline $\mathbf{V}$ & Economic value (ECO): 3 items & \\
\hline 1 & An above-average basic salary & Berthon et al. (2005) \\
\hline 2 & An attractive overall compensation package & Berthon et al. (2005) \\
\hline \multirow[t]{2}{*}{3} & My organization has good allowances for employees & Qualitative research \\
\hline & \multicolumn{2}{|l|}{ Total: 22 items } \\
\hline
\end{tabular}

Source: The researcher's data analysis 


\section{Data analysis}

\subsection{Cronbach's Alpha}

This study also uses Cronbach's Alpha testing to check scale reliability. To test the scale internal consistency, the author uses the results of factor analysis (EFA).

From Table 3, all scales meet the reliability requirements: Cronbach's Alpha of the scales is greater than 0.8. No item, if deleted, creates the Cronbach's Alpha larger than the original value; therefore, all items must be maintained.

Table 2

Cronbach's Alpha results

SOC (Social value)

\begin{tabular}{|c|c|c|c|c|}
\hline \multicolumn{5}{|c|}{ Reliability Statistics } \\
\hline \multicolumn{3}{|c|}{ Cronbach's Alpha } & \multicolumn{2}{|c|}{$\mathbf{N}$ of Items } \\
\hline \multicolumn{3}{|c|}{0.911} & \multicolumn{2}{|r|}{6} \\
\hline \multicolumn{5}{|c|}{ Item-Total Statistics } \\
\hline & $\begin{array}{l}\text { Scale Mean if } \\
\text { Item Deleted }\end{array}$ & $\begin{array}{c}\text { Scale Variance if } \\
\text { Item Deleted }\end{array}$ & $\begin{array}{l}\text { Corrected Item- } \\
\text { Total Correlation }\end{array}$ & $\begin{array}{c}\text { Cronbach's Alpha if } \\
\text { Item Deleted }\end{array}$ \\
\hline SOC1 & 20.15 & 7.765 & .786 & .890 \\
\hline SOC2 & 20.25 & 7.882 & .766 & .893 \\
\hline SOC3 & 20.17 & 8.250 & .721 & .899 \\
\hline SOC4 & 20.16 & 7.608 & .788 & .889 \\
\hline SOC5 & 20.36 & 7.614 & .734 & .898 \\
\hline SOC6 & 20.21 & 8.021 & .720 & .899 \\
\hline
\end{tabular}

DEV (Development value)

\begin{tabular}{|c|c|}
\hline \multicolumn{2}{|c|}{ Reliability Statistics } \\
\hline Cronbach's Alpha & N of Items \\
\hline 0.902 & 6 \\
\hline
\end{tabular}

\begin{tabular}{|c|c|c|c|c|}
\hline \multicolumn{5}{|c|}{ Item-Total Statistics } \\
\hline & $\begin{array}{c}\text { Scale Mean if } \\
\text { Item Deleted }\end{array}$ & $\begin{array}{c}\text { Scale Variance if } \\
\text { Item Deleted }\end{array}$ & $\begin{array}{c}\text { Corrected Item- } \\
\text { Total Correlation }\end{array}$ & $\begin{array}{c}\text { Cronbach's Alpha if } \\
\text { Item Deleted }\end{array}$ \\
\hline DEV1 & 20.12 & 6.979 & .782 & .877 \\
\hline DEV2 & 20.08 & 6.893 & .793 & .875 \\
\hline DEV3 & 20.10 & 7.050 & .761 & .880 \\
\hline DEV4 & 20.22 & 6.973 & .749 & .882 \\
\hline DEV5 & 20.11 & 7.249 & .733 & .885 \\
\hline DEV6 & 20.23 & 7.619 & .579 & .907 \\
\hline
\end{tabular}


APP (Application value)

\begin{tabular}{|c|c|}
\hline \multicolumn{2}{|c|}{ Reliability Statistics } \\
\hline Cronbach's Alpha & N of Items \\
\hline 0.832 & 4 \\
\hline
\end{tabular}

\begin{tabular}{|c|c|c|c|c|}
\hline \multicolumn{5}{|c|}{ Item-Total Statistics } \\
\hline & $\begin{array}{c}\text { Scale Mean if } \\
\text { Item Deleted }\end{array}$ & $\begin{array}{c}\text { Scale Variance if } \\
\text { Item Deleted }\end{array}$ & $\begin{array}{c}\text { Corrected Item- } \\
\text { Total Correlation }\end{array}$ & $\begin{array}{c}\text { Cronbach's Alpha } \\
\text { if Item Deleted }\end{array}$ \\
\hline APP1 & 11.72 & 2.604 & .702 & .770 \\
\hline APP2 & 11.74 & 2.820 & .584 & .821 \\
\hline APP3 & 11.67 & 2.649 & .714 & .765 \\
\hline APP4 & 11.69 & 2.610 & .649 & .794 \\
\hline
\end{tabular}

SAF (Safety Value)

\begin{tabular}{|c|c|}
\hline \multicolumn{2}{|c|}{ Reliability Statistics } \\
\hline Cronbach's Alpha & N of Items \\
\hline 0.844 & 3 \\
\hline
\end{tabular}

\begin{tabular}{|c|c|c|c|c|}
\hline \multicolumn{5}{|c|}{ Item-Total Statistics } \\
\hline & $\begin{array}{c}\text { Scale Mean if } \\
\text { Item Deleted }\end{array}$ & $\begin{array}{c}\text { Scale Variance if } \\
\text { Item Deleted }\end{array}$ & $\begin{array}{c}\text { Corrected Item- } \\
\text { Total Correlation }\end{array}$ & $\begin{array}{c}\text { Cronbach's Alpha } \\
\text { if Item Deleted }\end{array}$ \\
\hline SAF1 & 8.31 & 1.386 & .771 & .726 \\
\hline SAF2 & 8.39 & 1.400 & .691 & .800 \\
\hline SAF3 & 8.32 & 1.402 & .670 & .821 \\
\hline
\end{tabular}

ECO (Economic value)

\begin{tabular}{|c|c|}
\hline \multicolumn{2}{|c|}{ Reliability Statistics } \\
\hline Cronbach's Alpha & N of Items \\
\hline 0.849 & 3 \\
\hline
\end{tabular}

\begin{tabular}{|c|c|c|c|c|}
\hline \multicolumn{5}{|c|}{ Item-Total Statistics } \\
\hline & $\begin{array}{c}\text { Scale Mean if } \\
\text { Item Deleted }\end{array}$ & $\begin{array}{c}\text { Scale Variance if } \\
\text { Item Deleted }\end{array}$ & $\begin{array}{c}\text { Corrected Item- } \\
\text { Total Correlation }\end{array}$ & $\begin{array}{c}\text { Cronbach's Alpha } \\
\text { if Item Deleted }\end{array}$ \\
\hline ECO1 & 7.44 & 2.031 & .700 & .806 \\
\hline ECO2 & 7.31 & 1.817 & .797 & .710 \\
\hline ECO3 & 7.05 & 2.123 & .662 & .841 \\
\hline
\end{tabular}




\subsection{Explore Factor Analysis (EFA)}

From Table 3, the KMO index reaches 0.948 and ranges from [0.5 - 1] indicates that the scale is suitable. The significance in Bartlett's test has a value of $0.000(<0.05)$, a standard fit (Hair et al., 2017), proves that this scale is in accordance with the exploratory factor analysis (EFA) criteria. That the eigenvalue of the employer branding factor is 5 (Gerbing \& Anderson, 1988) shows that the number of factors is 5: social value (SOC), development value (DEV), application value (APP), safety value (SAF) and economic value (ECO). Moreover, that the Total Variance Explained index reaches $71.583 \%$ (> 50\%) meets the required standard (Gerbing \& Anderson, 1988). Finally, Factor loading shows the correlation level between observed variables and factors. That most items reach values of more than 0.5 means that the relationship between all observed variables in different factors, the value of association capacitor and the discriminant value of the scale achieve the criteria requirement.

In addition, the employer attractiveness scales achieve the internal consistency reliability requirement: Composite Reliability (CR) value is greater than 0.70 and convergent validity with Average Variance Extracted (AVE) is greater than 0.50.

\section{Table 3}

The Exploratory Factor Analysis (EFA) results

\begin{tabular}{|c|c|c|c|c|c|}
\hline & \multicolumn{5}{|c|}{ Component (Loading factor) } \\
\hline & SOC & DEV & APP & SAF & ECO \\
\hline SOC1 & 0.795 & & & & \\
\hline SOC2 & 0.768 & & & & \\
\hline SOC3 & 0.734 & & & & \\
\hline SOC4 & 0.728 & & & & \\
\hline SOC5 & 0.709 & & & & \\
\hline SOC6 & 0.700 & & & & \\
\hline DEV1 & & 0.771 & & & \\
\hline DEV2 & & 0.755 & & & \\
\hline DEV3 & & 0.744 & & & \\
\hline DEV4 & & 0.660 & & & \\
\hline DEV5 & & 0.568 & & & \\
\hline DEV6 & & 0.562 & & & \\
\hline APP1 & & & 0.833 & & \\
\hline APP2 & & & 0.729 & & \\
\hline APP3 & & & 0.715 & & \\
\hline APP4 & & & 0.565 & & \\
\hline SAF1 & & & & 0.819 & \\
\hline SAF2 & & & & 0.735 & \\
\hline SAF3 & & & & 0.727 & \\
\hline ECO1 & & & & & 0.838 \\
\hline $\mathrm{ECO} 2$ & & & & & 0.832 \\
\hline $\mathrm{ECO} 3$ & & & & & 0.653 \\
\hline Composite Reliability (CR) & 0.931 & 0.925 & 0.889 & 0.906 & 0.908 \\
\hline AVE & 0.694 & 0.674 & 0.666 & 0.764 & 0.767 \\
\hline
\end{tabular}

KMO: $0.948(>0.5)$

Bartlett's Test of Sphericity: Sig $=0.000(<0.05)$.

Cumulative \%: $71.583 \%$ (> 50\%).

Eigenvalues: 5 (> 1.0)

Source: Data analysis result of the research 


\section{Discussion}

Employer branding scale is based on the definition by Berthon et al. (2005): Employer Attractiveness refers to the organizational benefits (interesting value, economic value, social value, developmental value and application value) recognized by potential candidates as one special organization to work in. From this definition, the study, based on Berthon et al.'s definition (2005) and qualitative research, has developed an employer attractiveness scale. In particular, Berthon et al. (2005) use economic value (ECO), social value (SOC), developmental value (DEV) and application value (APP). Interesting value is not mentioned in this study because the scale content is not appropriate in Vietnamese business contexts. Employer Attractiveness scale adds an important factor in the current Vietnamese business period, that is safety factor. Safety value scale, based on qualitative research, separates 1 item from ECO (Berthon et al., 2005): "Job security within the organization". This Safety factor is addressed in measuring content safety at all working processes (SAF1: "The organization I work with always ensures occupational safety during work activities"). In addition, safety concerns consist of physical, psychological and mental issues. Safety issues for sexual abuse included in Labor Code provisions by Vietnamese government (SAF3: The organization I work with is always safe in the work environment (without pressure, sexual harassment, etc.)). In addition, the safety factor will have a positive effect on employee engagement in companies (Brown \& Leigh, 1996; Hendler, 2012; Lyu, 2016); therefore, in Vietnamese research context, safety factor is attractive to potential candidates.

For the remaining factors, the study has added more items. For example, social factors include 'Colleagues in the company always get along with each other' which clarifies the relationship among organization members better in harmony. This social value is what employees expect to receive from the organization. For development value, some differences compared to the original scale of Berthon et al. (2005) are identified: 2 more contents, including the employee's desire to have the opportunity to experience in a professional environment. ("You feel the desire to stick with the organization because of the opportunities that come from experience in a professional workplace") and wish to be delegated to practice work skills for development ("My organization always implements decentralized employee"). Additionally, research has shown that management recognition ('recognition/appreciation form management') is not a significant content in employees' growth value perception. For the application factor, two items unsuitable for the research context should be excluded from the construct of this factor: "Humanitarian organization - gives back to society" and "The organization is customer-orientated". Because of the human sense of an organization as well as the customer-focused orientation, it is more social, rather than demonstrating the value of the employee's application to the organization's activities. The study results also add another application content in an organization that is experience sharing ("You have the opportunity to share your real experiences with everyone in the organization"). These items help complement the employee's application value in the organization more fully, including teaching what is learned, applying what is learned, sharing experiences and feeling accepted at the organization. Finally, the construct of the economic factor, according to the results of this study, is quite different from the original scale. Accordingly, the item "good promotion opportunities within the organization" are excluded because the meaning of this content is oriented towards career development (related to development value) rather than economic value. Similarly, item "job security within the organization" is excluded from economic value because this content is related to the safety factor in the organization, not the economic issue of the employee. The other "hands-on inter-departmental experience" excluded item is related to the experience of interdepartmental experiences in the organization. In contrast, in terms of the economic factor, the 
added factor of the company has an allowances system for employees helps to fully complement aspects of economic value.

\section{Conclusion and managerial suggestions}

Social factors always play a very important role in attracting and retaining talents. In order to build this value well at the enterprise, managers need to note that it is necessary to build well all 3 aspects: a good working environment, creating a good working relationship and a good team atmosphere within the company. For the working environment, to ensure both fun and happiness helps employees to have a comfortable and happy spirit when they come to work every day. Managers must make employees feel that they belong to the organization and the people there. Next, building good relationships should be done between colleagues as well as superiors and subordinates. Finally, the company must always encourage employees in helping and motivating each other at work. Besides social factors, the development factor is also very crucial for attracting potential candidates. Accordingly, managers need to provide employees with awareness, confidence and engagement to professional experience, especially, the foundation for future development. In terms of perception, how employees feel they belong to the organization because the opportunities come from professional working environment experience and feel themselves as a result of a team. From there, helping employees feel more confident. In addition, enabling employees to experience the experience and accumulate knowledge to create a development platform for the future is of great value in employee development. Finally, managers need to increase authorization to enable employees to perform challenging and critical jobs with the purpose of helping employees to train and improve their working capacity. Next, giving employees the opportunity to apply what they have learned to teach others as well as create a customeroriented and humane working environment also helps to make a good impression on the mind of the employee. In application value, managers can enable employees to teach and share what they learn from schools and from their working experience. This will give employees great motivation and their contribution value to the organization and society. At the same time, managers should create a feeling of being welcome and belonging to the organization working for the employees: The organization is aiming for humanitarian values in the corporate culture.

This study also develops employer attractiveness scale with a new factor: safety value - a very important factor for employees in the current period when the physical and psychological safety issues are increasingly concerned and valued by companies. With 3 items: "The organization I work with always ensures occupational safety during work activities" "Job security within the organization" and "The organization I work with is always safe in the work environment (without pressure, sexual harassment, etc.)", the scale covers all aspects of safety value in the working environment. Through scale testing, safety value completely meets the standards to become the factor in employer attractiveness scale. Practically, this scale is suitable for the current trend of applying sustainable development business strategies in Vietnam. Last but not least, it is necessary to give employees financial benefits. A salary above the market average is the expectation of any employee. Therefore, in terms of budget allows, managers, need to pay attention to building competitive wages for employees. In addition, companies can design attractive bonus and benefits packages to attract and retain talent. The discovery and addition of the safety value factor in the employer attractiveness scale will help supplement the employer branding theory in terms of conceptually and the scale of this factor. Accordingly, the term employer attractiveness will be included in ensuring the safety of the employee both physically and mentally. 


\section{Limitations and future research}

Because the sampling method of the study is a non-probabilistic method, namely convenient sampling, the representativeness of the population has many limitations. Respondents work mainly in enterprises so this scale can only represent business organizations but has not yet reached the totality for all types of organizations (socio-political organizations, state management agencies, non-profit organizations, associations, clubs, etc.). Another limitation of this study is the data collected from firms located in major cities in southern Vietnam. Due to the differences in culture and personality between regions in Vietnam, research results are also affected. Moreover, in terms of the timeframe of data retrieval, this study only takes data at the fixed time without sufficient data at different times for comparison. This makes it impractical to evaluate an employee's perception changes towards employer branding at different time intervals. This limitation also affects the research results.

The future research directions can be referenced, including survey methods, data collection and new research factors. First, that the follow-up studies can survey respondents in a wider scope and across the country will help increase the overall coverage and reliability of the scale. Likewise, another research direction, which extends surveys at other organization types, includes sociopolitical organizations, state management agencies, non-profit organizations, associations, clubs, etc. Next, the sampling method can use the probability method as well as be performed at different times to compare the changes in the candidate's perception. Therefore, the scale will be more accurate and reliable. In addition, it is possible to study the effect of employer attractiveness on current employee factors (engagement, satisfaction, work performance, work motivation, etc.).

\section{References}

Aaker, D. A., \& Equity, M. B. (1991). Capitalizing on the value of a brand name. New York, 28(1), 35-37.

Ambler, T., \& Barrow, S. (1996). The employer brand. Journal of Brand Management, 4(3), 185-206.

Ash, R. A., \& Bendapudi, V. (1996). Revisiting the measurement of pay satisfaction: Testing an improved measure. Presented at the 11th Annual Conference of the Society for Industrial and Organizational Psychology, San Diego, CA.

Aurand, T. W., Gorchels, L., \& Bishop, T. R. (2005). Human resource management's role in internal branding: An opportunity for cross-functional brand message synergy. Journal of Product \& Brand Management, 14(2), 163-169.

Baruch, Y. (2004). Transforming careers: From linear to multidirectional career paths: Organizational and individual perspectives. Career Development International, 9(1), 58-73.

Bergstrom, A., Blumenthal, D., \& Crothers, S. (2002). Why internal branding matters: The case of Saab. Corporate Reputation Review, 5(2/3), 133-142.

Berthon, P., Ewing, M., \& Hah, L. L. (2005), Captivating company: Dimensions of attractiveness in employer branding. International Journal of Advertising, 24(2), 151-172.

Blau, P. M. (1964). Exchange and power in social life. New Brunswick, NJ: Transaction Publishers.

Brown, S. P., \& Leigh, T. W. (1996). A new look at psychological climate and its relationship to job involvement, effort, and performance. Journal of Applied Psychology, 81(4), 358- 368. 
Burmann, C., \& Zeplin, S. (2005). Building brand commitment: A behavioural approach to internal brand building. Journal of Brand Management, 12(4), 279-300.

Chew, J., \& Chan, C. C. (2008). Human resource practices, organizational commitment and intention to stay. International Journal of Manpower, 29(6), 503-522.

Collins, C. J., \& Stevens, C. K. (2002). The relationship between early recruitment-related activities and the application decisions of new labor-market entrants: A brand equity approach to recruitment. Journal of Applied Psychology, 87(6), 1121-1133.

de Chernatony, L. (2002). Would a brand smell any sweeter by a corporate name? Corporate Reputation Review, 5(2/3), 115-132.

de Chernatony, L., \& Segal-Horn, S. (2001). Building on services characteristics to develop successful services brands. Journal of Marketing Management, 17(7/8), 645-669.

De Vos, A., \& Meganck, A. (2009). What HR managers do versus what employees value. Personnel Review, 38(1), 45-60.

Donavan, D. T., Brown, T. J., \& Mowen, J. C. (2004). Internal benefits of service-worker customer orientation: Job satisfaction, commitment, and organizational citizenship behaviors. Journal of Marketing, 68(1), 128-146.

Drake, S. M., Gulman, M. J., \& Roberts, S. M. (2005). Light their fire. Chicago, IL: Dearborn.

Edwards, M. R. (2010). An integrative review of employer branding and OB theory. Personnel Review, 39(1), 5-23.

Elving, W. J., Westhoff, J. J., Meeusen, K., \& Schoonderbeek, J. W. (2013). The war for talent? The relevance of employer branding in job advertisements for becoming an employer of choice. Journal of Brand Management, 20(5), 355-373.

Emerson, R. M. (1976). Social exchange theory. Annual Review Of Sociology, 2(1), 335-362.

Gatewood, R. D., Gowan, M. A., \& Lautenschlager, G. J. (1993). Corporate image, recruitment image and initial job choice decisions. Academy of Management Journal, 36(2), 414-427.

Gerbing, D. W., \& Anderson, J. C. (1988). An updated paradigm for scale development incorporating unidimensionality and its assessment. Journal of Marketing Research, 25(2), 186-192.

Hair, J. F., Jr., Sarstedt, M., Ringle, C. M., \& Gudergan, S. P. (2017). Advanced issues in partial least squares structural equation modeling. London, UK: Sage Publications.

Harris, F., \& de Chernatony, L. (2001) Corporate branding and corporate brand performance. European Journal of Marketing, 35(3/4), 441-451.

Hendler, D. (2012). Psychological safety as a mediating variable in the relationship between ethical leadership and employee engagement at work(Doctoral dissertation). Johannesburg, Gauteng, South Africa.

Hendry, C., \& Jenkins, R. (1997). Psychological contracts and new deals. Human Resource Management Journal, 7(1), 38-44.

Jacobs, R. (2003). Turn employees into brand ambassadors. Bank Marketing, 35(3), 22-26.

Jiang, T., \& Iles, P. (2011). Employer-brand equity, organizational attractiveness and talent management in the Zhejiang private sector, China. Journal of Technology Management in China, 6(1), 97-110. 
Jurgensen, C. E. (1978). Job preferences: What makes a job good or bad? Journal of Applied Psychology, 63, 267-276.

Kahn, W. A. (1990). Psychological conditions of personal engagement and disengagement at work. Academy of Management Journal, 33(4), 692-724.

Keller, K. L. (1993). Conceptualizing, measuring, and managing customer-based brand equity. Journal of Marketing, 57(1), 1-22.

King, C., \& Grace, D. (2008). Internal branding: Exploring the employee's perspective. Journal of Brand Management, 15(5), 358-372.

Kyndt, E., Dochy, F., \& Nijs, H. (2009). Learning conditions for non-formal and informal workplace learning. Journal of Workplace Learning, 21(5), 369-383.

Lee, S. M. (1971). An empirical analysis of organizational identification. Academy of Management Journal, 14(2), 213-226.

Lyu, X. (2016). Effect of organizational justice on work engagement with psychological safety as a mediator: Evidence from China. Social Behavior and Personality: An International Journal, 44(8), 1359-1370.

Newell, H., \& Dopson, S. (1996). Muddle in the middle: Organizational restructuring and middle management careers. Personnel Review, 25(4), 4-20.

Paré, G., \& Tremblay, M. (2007). The influence of high-involvement human resources practices, procedural justice, organizational commitment, and citizenship behaviors on information technology professionals' turnover intentions. Group \& Organization Management, 32(3), 326-357.

Paré, G., Tremblay, M., \& Lalonde, P. (2001). Workforce retention: What do IT employees really want? Proceedings of the 2001 ACM SIGCPR Conference on Computer Personnel Research, 1-10.

Parsley, A. (2005). Employee engagement: The what, why and how. Retrieved June 7, 2009, from http://www.management-issues.com/2006/5/25/opinion/a-road-map-for-employeeengagement.asp

Pingle, S. S., \& Sharma, A. (2013). External employer attractiveness: A study of management students in India. Journal of Contemporary Management Research, 7(1), 78-95.

Pringle, H., \& Thompson, M. (2001). Brand spirit. Chichester, UK: Wiley.

Schlager, T., Bodderas, M., Maas, P., \& Cachelin, J. L. (2011). The influence of the employer brand on employee attitudes relevant for service branding: An empirical investigation, Journal of Services Marketing, 25(7), 497-508.

Schneider, B., Macey, W. H., Barbera, K. M., \& Young, S. A. (2010). The role of employee trust in understanding employee engagement. In Handbook of employee engagement: Perspectives, issues, research and practice (pp. 159-173). Cheltenham, UK: Edward Elgar.

Schreurs, B., Druart, C., Proost, K., \& De Witte, K. (2009). Symbolic attributes and organizational attractiveness: The moderating effects of applicant personality. International Journal of Selection and Assessment, 17(1), 35-46.

Sheridan, J. E. (1992). Organizational culture and employee retention. Academy of Management Journal, 35(5), 1036-1056.

Shore, L. M., \& Coyle-Shapiro, J. A. M. (2003). New developments in the employee -organization relationship. Journal of Organizational Behavior: The International Journal of Industrial, 
Occupational and Organizational Psychology and Behavior, 24(5), 443-450.

Shore, L. M., Coyle-Shapiro, J. A., Chen, X. P., \& Tetrick, L. E. (2009). Social exchange in work settings: Content, process, and mixed models. Management and Organization Review, 5(3), 289-302.

Soutar, G. N., \& Clarke, A. W. (1983). Examining business students' career preferences: A perceptual space approach. Journal of Vocational Behavior, 23(1), 11-21.

Spence, M. (1973). Job market signaling. Quarterly Journal of Economics, 87(3), 355-374.

Tabachnick, B. G., Fidell, L. S., \& Ullman, J. B. (2007). Using multivariate statistics. Boston, MA: Pearson.

Tansky, J. W., \& Cohen, D. J. (2001). The relationship between organizational support, employee development, and organizational commitment: An empirical study. Human Resource Development Quarterly, 12(3), 285-300.

Taormina, R. J. (2009). Organizational socialization: The missing link between employee needs and organizational culture. Journal of Managerial Psychology, 24(7), 650-676.

Thomson, K., de Chernatony, L., Arganbright, L., \& Khan, S. (1999). The buy-in benchmark: How staff understanding and commitment impact brand and business performance. Journal of Marketing Management, 15(8), 819-835.

Zheng, C., \& Lamond, D. (2010). Organisational determinants of employee turnover for multinational companies in Asia. Asia Pacific Journal Of Management, 27(3), 423-443.

Zohar, D., Huang, Y. H., Lee, J., \& Robertson, M. M. (2015). Testing extrinsic and intrinsic motivation as explanatory variables for the safety climate-safety performance relationship among long-haul truck drivers. Transportation Research Part F: Traffic Psychology and Behaviour, 30, 84-96. 


\section{APPENDIX}

\section{Employer attractiveness scale}

\begin{tabular}{|c|l|}
\hline No. & Items \\
\hline 1. Social value \\
\hline 1 & Colleagues in the company always get along with each other. \\
\hline 2 & Having a good relationship with your colleagues. \\
\hline 3 & Supportive and encouraging colleagues. \\
\hline 4 & Having a good relationship with your superiors. \\
\hline 5 & Happy work environment. \\
\hline 6 & A fun working environment. \\
\hline
\end{tabular}

\section{Development value}

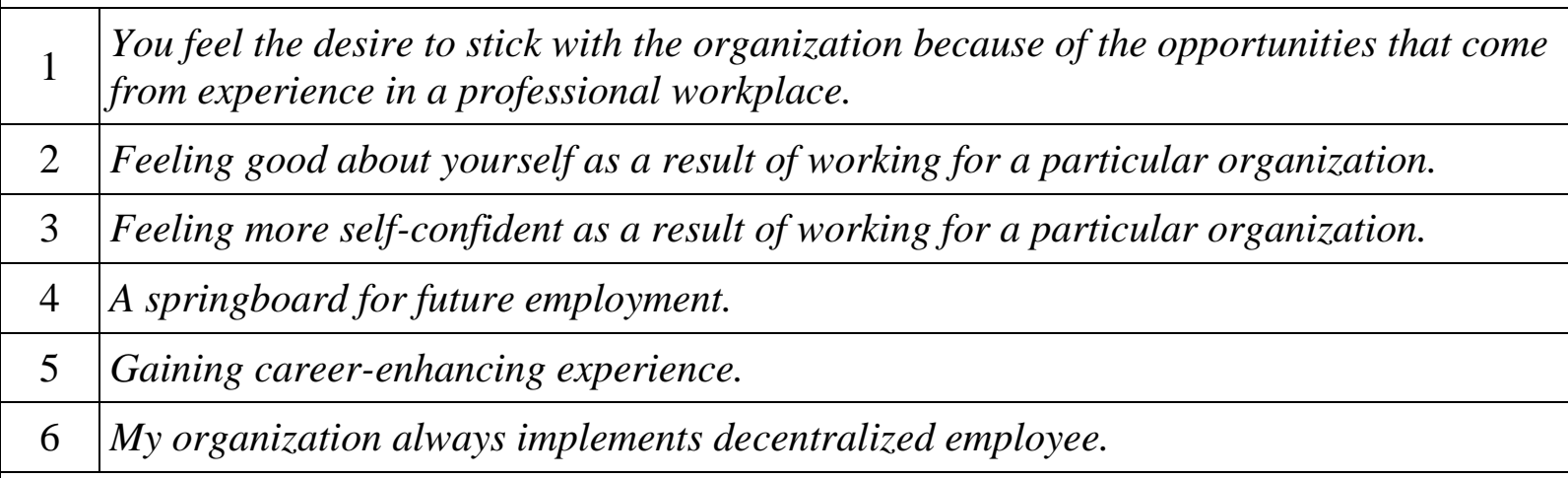

\section{Application value}

\begin{tabular}{|c|l}
\hline 1 & Opportunity to teach others what you have learned. \\
\hline 2 & Opportunity to apply what was learned at a tertiary institution. \\
\hline 3 & $\begin{array}{l}\text { You have the opportunity to share your real experiences with everyone in the } \\
\text { organization. }\end{array}$ \\
\hline 4 & Acceptance and belonging. \\
\hline
\end{tabular}

\section{Safety value}

\begin{tabular}{|c|l|}
\hline 1 & The organization I work with always ensures occupational safety during work activities. \\
\hline 2 & Job security within the organization. \\
\hline 3 & $\begin{array}{l}\text { The organization I work with is always safe in the work environment (without pressure, } \\
\text { sexual harassment, etc.). }\end{array}$ \\
\hline
\end{tabular}

\section{Economic value}

\begin{tabular}{|l|l|}
\hline 1 & An above average basic salary. \\
\hline 2 & An attractive overall compensation package. \\
\hline 3 & My organization has good allowances for employees. \\
\hline
\end{tabular}

